This is a self-archived version of an original article. This version may differ from the original in pagination and typographic details.

Author(s): Laitinen, Hanna

Title: Empowering New Agents of Civil Society or Fostering Good Citizens? : Framing Youth Participation in Finnish Youth Organizations

Year: 2018

Version: Accepted version (Final draft)

Copyright: @ 2018 Informa UK Limited, trading as Taylor \& Francis Group

Rights: In Copyright

Rights url: http://rightsstatements.org/page/InC/1.0/?language=en

Please cite the original version:

Laitinen, H. (2018). Empowering New Agents of Civil Society or Fostering Good Citizens? :

Framing Youth Participation in Finnish Youth Organizations. Journal of Civil Society, 14(4), 328-

345. https://doi.org/10.1080/17448689.2018.1518770 


\title{
Empowering New Agents of Civil Society or Fostering Good Citizens? Framing Youth Participation in Finnish Youth Organizations.
}

\author{
Abstract \\ This article investigates how nationwide Finnish youth civil society organizations \\ frame their approaches to youth participation. By analyzing data from interviews, \\ websites, and annual reports, five frames are identified. The frames differ in how \\ they define the purpose of participation, whom they see as the main actors, and \\ what kind of member, volunteer, or other participant roles they provide to young \\ people. Three frames are used as master frames that see young people as agents, \\ learners, or targets of support; two subordinate frames expand the scopes of the \\ organizations. Only some of the frames include any concept of integrating young \\ people into the civil society.
}

KEY WORDS: Youth participation, civil society organizations, membership, volunteering, frame analysis 


\section{Introduction}

This article brings together discussions of two issues: Participation in Civil Society Organizations (CSOs), and youth participation. CSOs play a vital role in mediating between the individual and the society by providing people with opportunities to participate in voicing collective concerns, helping others, taking part in recreational activities, and building the wellbeing of oneself and others in many other ways. However, there is concern regarding the future of CSOs as younger generations seem not to be interested in participating in them or taking responsibility for their future existence. Research on youth civic engagement tells us that young people are turning away from established political and civil society organizations, are less willing to join as members and prefer short-term volunteering to long-term commitments (Flash Eurobarometer, 2013; Harris et al., 2010; Lochocki, 2010; Merikivi et al., 2016).

The focus of this article is to understand what CSOs as organizations do in this situation. How do established CSOs define their approaches to participation by young people and what are the practical ways in which they invite young people to join and become attached to the organizations? The methodological approach is based on frame analysis of interviews, websites and annual reports derived from a group of CSOs that can be seen as specialists on the needs and interests of young people in a favourable environment: Youth CSOs in Finland. The case country, Finland, has a long tradition of associational life appreciated by both the state and the people, who join associations in high numbers, even though the trend for less engagement by young people is also true of Finland (Siisiäinen \& Blom, 2009).

The characteristics, developments and changes of participation in civil society have been important targets of research throughout the beginning of the $21^{\text {st }}$ century (e.g., Barrett \& Brunton-Smith, 2014; Holmes \& Slater, 2012; Hustinx \& Denk, 2009; Putnam, 2000; Schofer \& Fourcade-Gourinchas, 2001; Siisiäinen \& Blom, 2009; Skocpol, 2003; van Ingen, 2009). At the same time, there is a rich body of literature describing the various phenomena of youth participation and looking for ways to enable, encourage, and support young people to become active agents in shaping their lives and democratic structures around them (Feldmann-Wojtachnia et al., 2010; Gretschel et al., 2014; Hart, 1992; Shaw et al., 2014; Thomas, 2007; Tsekoura, 2016). What is missing, however, is an understanding of youth participation in the context of CSOs. This article aims to fill that gap.

The two main questions of this article are: How do Finnish youth CSOs frame their approaches to youth participation? How do these framed approaches materialize into practical participation opportunities? By answering these questions, the article will show the importance of understanding the role of CSOs in defining the scope of and practical opportunities for participation and thus creating the environment for young people's attachment to CSOs.

In the beginning of the article, I set the context and introduce the main concepts used later in the article by examining what previous research tells us about participation in CSOs and what we know about youth participation as a phenomenon. I then continue to describe what is unique about the Finnish civil society and Finnish approaches to youth 
participation, followed by a description of the empirical data and research methods. In the remaining chapters, I present the results of my research and draw conclusions on what my findings tell us about the role of CSOs in enabling youth participation and contributing to the future existence of CSOs.

\section{Participation in Civil Society Organizations: Membership and Volunteering}

One of the key elements and functions of CSOs is to provide people with opportunities to take various roles in social (van Ingen, 2009) or citizen participation (Hustinx \& Denk, 2009). When studying the features of participation in CSOs, the focus is mostly on active voluntary participation in contrast to passive participation or engagement as a mere interest or positive attitude towards political or civic matters (Barrett \& Brunton-Smith, 2014). Moreover, the focus is on participation channeled into or through an organization, i.e., associational involvement (van der Meer et al., 2009), which leaves out activity that takes place individually, in ad-hoc action or in social movements without organizational connections. Focusing on the study of involvement in CSOs, two key concepts stand out: Membership and volunteering.

In its simplest form, membership can be seen as just a single action of joining an association as a passive member (van Ingen, 2009). In organizations connected to older social movements, for example trade unions, the mere act of paying a membership fee has been a normal way of supporting the movement and giving its leaders a mandate to act on behalf of and in the interests of the individual member (Siisiäinen \& Blom, 2009). Now this type of checkbook membership also seems to be getting more common in professionally managed tertiary organizations belonging to newer social movements, for example environmental and human rights organizations, that encourage people to support them financially without needing to use time on collective face-to-face membership activities (Lorentzen \& Hustinx, 2007; Putnam, 2000; Skocpol, 2003).

Nevertheless, the ideal picture of membership in voluntary associations consists of active members who are involved in various tasks and at several levels of the association (Billis, 2010). Ideally, this means that in addition to paying a membership fee and participating in activities arranged by others as pay and players (Holmes \& Slater, 2012) or as member-consumers (Lorentzen \& Hustinx, 2007), active members participate in organizing activities for themselves and others. Moreover, they take on responsibilities on boards and in other decision-making bodies.

The rise of new concepts such as checkbook members, pay and players, and memberconsumers suggests that member roles are changing. However, not all studies support this hypothesis (see, e.g., van der Roest et al., 2016; Walker et al., 2011). This could have several explanations. In addition to national cultures being statist or non-statist, corporate or non-corporate, or countries being in economically high or low situations (Schofer \& Fourcade-Gourinchas, 2001), differences at the organizational level also play a role. As stated already by Michels ([1911] 1962), the bigger an organization grows, the more oligarchic or bureaucratic it becomes, and the less space members have to influence decision-making; a manifestation of this tendency is that there is often more space for pay and play roles in bigger than in smaller associations (Holmes \& Slater, 2012). 
Additionally, the primary aim of the organization makes a difference: The repertoires of activities are different in, e.g., interest, activist and leisure organizations (van der Meer et al., 2009). In sum, it seems more likely that there is no one overall trend but that membership takes different forms in different coexisting organizations and in varying national contexts.

Active membership entails voluntary inputs and can be seen as forming one part of the conceptual contents of volunteering. However, volunteering is normally not bound to membership. Instead, any type of organization, independent of its membership arrangements, can arrange volunteering opportunities.

What then is volunteering? Benevolent volunteering refers to situations where volunteers provide care or in other ways help other people in need, as 'unpaid work or service' often within the field of social service (Rochester et al., 2010). Volunteering as leisure (Stebbins \& Graham, 2004) sees volunteering as a way to spend free time. Within this, volunteering as project-based leisure is a time-bound project, e.g., arranging a happening; volunteering as casual leisure can take place occasionally, for example in selling tickets in a larger happening; and an example of volunteering as serious leisure could be acting as a group tutor for children (Stebbins, 2004). Volunteering as associational activism includes active participation in grassroots associations and community groups (Rochester et al., 2010). This type comes close to active membership, but in the framework of volunteering, it does not necessarily require membership. Volunteering can additionally take the form of political activism that includes volunteer inputs in advocacy work or political campaigns aiming to cause changes in the society (Henriksen \& Svedberg, 2010; Hustinx \& Denk, 2009).

In order to attract potential volunteers, CSOs offer various types of volunteering opportunities. Today, many organizations base these menus of volunteering (Hustinx, 2010) on an understanding that the motivation of volunteers has changed from serving community values to fulfilling personal interests and constructing an individual biography, i.e., from collective to reflexive volunteering (Hustinx \& Lammertyn, 2003). Reacting to the overall individualization of our societies, volunteers are seen as preferring short-term, non-binding options where volunteering does not necessarily include belonging to a group but can be done alone, i.e., episodic or plug-in volunteering (Eliasoph, 2011; Hustinx, 2010). The critical question raised by some researchers is whether or not this reshaping of volunteering opportunities causes individualized volunteering in itself (Hustinx, 2010; Read, 2010).

The theory of hybrid organizations explains the changing role of members and volunteers by stating that hybrid CSOs take on resources, working methods, and principles from private and public sectors, employ professionals, and - by so doing distance themselves from the original third sector (Billis, 2010). Increased hybridity results in a diminishing role of members and volunteers. In the ideal type of voluntary association, the volunteer members themselves have ownership of the organization; in shallow hybrids they are members with some power; and in deeply rooted 'entrenched hybrids' (Billis, 2010, p. 60), paid staff become the dominant actors of the organization. This means that volunteers are seen as one type of resource that is managed by the staff 
and needed to reach the objectives of the organization, but no longer as the CSO's reason for existence (Ellis Paine et al., 2010).

\section{Youth Participation}

The study of youth participation (youth civic engagement) ${ }^{i}$ is often motivated by a concern for the future of democracy and active citizenship, as younger generations seem to show relatively little interest in political and social participation (e.g. Harris et al., 2010; Lochocki, 2010). Quantitative studies like the Flash Eurobarometer survey (2013) have observed that the number of young people who vote in national elections has decreased and many are not interested in associational activities. However, researchers also suggest that what may be changing is not the interest in participation as such but the channels and ways of doing it. Young people prefer informal ways of engagement, participate in short-term or episodic volunteering and focus on specific issues instead of devoting themselves to broad and long-term agendas in established CSOs (Harris et al., 2010; Lochocki, 2010). At the same time, studies show that involved youth tend to belong to more advantaged social groups, which means that less educated youth and those coming from economically less privileged families are more often left out (FeldmannWojtacnia et al., 2010; Lochocki, 2010).

One common way of defining youth participation is based on the ideals of democracy, the right of young people to get their voices heard and to be part of decisionmaking processes in issues affecting them (Feldmann-Wojtacnia et al., 2010; Shaw et al., 2014). Research inspired by a need to understand how these ideals are met sees participation essentially as a question of power (Hart, 1992) and agency (FeldmannWojtacnia et al., 2010) that is negotiated in relationships between adults and young people. The theoretical background is in the ladder of young people's participation (Hart, 1992), which describes changing relationships between adults and young people. The lowest rungs on the ladder are, in effect, non-participation, and include manipulation, decoration, and tokenism; the remaining five rungs are 'degrees of participation'. On the lower participation rungs, adults are responsible for the activities and have youth volunteer for them. Climbing the steps, young people take on more responsibility, initiative, and decision-making power, and on the top rung, they initiate projects and invite adults to join in decision-making (Hart, 1992).

However, critical voices claim that this model is too simplistic and focuses only on those young people who are already active and interested in participating in the adult world, i.e., 'young adults' (Thomas, 2007). It is also criticized for regenerating old structures and emphasizing adults' agendas, knowledge, and language, which all lead to mimicking the adult world instead of fostering new ways of thinking (Thomas, 2007; Tsekoura, 2016).

A second approach to youth participation focuses on the individual young participant and sees participation essentially as a learning opportunity. This can take place in democratic structures as described above, but also in other types of situations where the learning process itself is more important than the outcome (Shaw et al., 2014). In this approach, participation is seen as a means to positive youth development (PYD) that 
consists of competence, confidence, character, connection, caring, and contribution (Lerner et al., 2005; Thomas, 2007). It can also take place in creative spaces where young people have the opportunity to freely decide what they want to do and how to do it, which can be a good opportunity for learning and developing skills for later use in other arenas (Tsekoura, 2016).

In addition to these two very commonly used approaches, Shaw et al. (2014) introduce three discourses, belonging, care, and social justice, which present youth participation as a desirable effort. All of them focus on specific groups of young people and an understanding that some young people need more support than others to find active roles in the society. In the discourse of belonging, opening opportunities for participation is seen as a way for youth at risk of exclusion to gain feelings of being part of a community. The discourse of care pays attention to engagement in civic matters as a way for vulnerable youth to develop skills that enhance their resilience. Thirdly, the discourse of social justice focuses on marginalized youth who are empowered to become aware of their situation and supported to work for justice. This approach thus acknowledges that the reasons behind marginalized and vulnerable situations are structural and cannot be changed by personal development or care only.

A sixth approach sees young people as consumers whose participation is important to improve the services and products provided to them (Feldmann-Wojtacnia et al., 2010).

\section{Civil Society Organizations and Youth Participation in Finland}

Civil society organizations are well appreciated in the Finnish context. In international comparisons, Finland is one of the Scandinavian non-statist, corporate countries where civic engagement is supported both culturally and practically by the state, where a plurality of associations exists, where citizen participation is primarily channeled collectively through voluntary associations, and where CSOs focus less on social services and more on advocacy, recreation and other expressive functions (Salamon et al., 2003; Schofer \& Fourcade-Gourinchas, 2001; Siisiäinen \& Blom, 2009). National federations and umbrella organizations typically have a relatively close, mutual relationship with the state: they receive funding from government agencies, but also expect to be able to influence them (Siisiäinen \& Blom, 2009). Despite the close relationship, fees and other private fundraising constitute, on average, a larger share of CSO revenues than public funding (Salamon et al, 2003, p. 32; Peltosalmi et al., 2016, p. 81).

The vast majority of CSOs are established as registered associations. According to the Associations Act (1989), the decisions of an association are made in the meetings of the association, and all members 15 years or older have the right to vote. There is thus a clear emphasis on member participation and organizational democracy in the institutional idea of voluntary associations in Finland. However, there are also associations and foundations with strong hybrid characters, small numbers of members, and specific missions that they carry out on a professional basis.

On average, Finnish people are eager to join associations. The percentage of people that do not have any memberships declined consistently during 1972-2005, and in 
2005 only 13\% of Finns were not members in any association (Siisiäinen \& Blom, 2009). However, the situation is different among young people between the ages of ten and 29. $49 \%$ of them said in 2016 that they were not members in any association (Merikivi et al., 2016).

Finnish nationwide youth CSOs include federations, umbrella organizations, foundations and associations with direct individual members. Many of them participate actively in discussions concerning youth policy in Finland. The main governmental sponsor is the Ministry for Education and Culture, whose funding aims to support youth civic involvement on a very broad spectrum. Another important sponsor is the Funding Centre for Social Welfare and Health Organisations, whose main purpose is to promote health and social welfare by focusing on specific target groups. The newly revised Youth Act (2016) emphasizes the need for youth participation, empowerment, growth, independence, belonging, and learning.

In the Finnish society, youth participation is often defined in the context of democracy, e.g. being part of planning and decision-making processes especially at the local level (Gretschel et al., 2014). At the same time, the ideas of participation as learning, belonging, and care co-exist (Feldmann-Wojtacnia et al., 2010). Despite subsequent government policies and programs aiming to increase youth participation, youth researchers have found a lot of space for improvement in enabling youth influence on

public decision making and empowering participation by more diverse groups of young people and marginalized youth (ibid; Gretschel et al., 2014).

\section{Methodology and Data}

This research investigates how youth participation is defined and practiced in Finnish nationwide youth CSOs. Empirically, the focus is on the whole population of nationwide Finnish youth CSOs with a minimum of one employee. The CSOs are defined as youth CSOs by the main interest of the organization, implying that they are either established and managed by young people themselves to promote their political, ideological or other 'youth' interest, or the main purpose is based on an educational, caretaking or other 'adult' interest towards youth (Siisiäinen 1988). ${ }^{\text {ii }}$ This leaves out, for example, sports associations that also arrange activities for young people, but identify themselves primarily as something other than a youth organization. An overview of the 82 youth CSOs in the data can be found in Table 1. 
Table 1: Finnish nationwide youth CSOs that have a minimum of one employee.

\begin{tabular}{|l|l|l|}
\hline $\begin{array}{l}\text { Category based on the main } \\
\text { purpose in relation to youth }\end{array}$ & Examples & $\begin{array}{l}\text { Estimate of the } \\
\text { proportion } \\
\text { organizations } \\
\text { oflonging to the } \\
\text { tategory }(\mathrm{n}=82) *\end{array}$ \\
\hline Leisure time organizations & $\begin{array}{l}\text { CSOs that organize hobbies, cultural activities, } \\
\text { etc. }\end{array}$ & $25-30 \%$ \\
\hline $\begin{array}{l}\text { Social reinforcement and } \\
\text { youth education } \\
\text { organizations }\end{array}$ & $\begin{array}{l}\text { CSOs dealing with drug prevention, services for } \\
\text { youth at risk, educational activities, etc. }\end{array}$ & $20-25 \%$ \\
\hline $\begin{array}{l}\text { Youth interest organizations } \\
\text { fortivist organizations }\end{array}$ & $\begin{array}{l}\text { Student organizations, others promoting the } \\
\text { interests of young people }\end{array}$ & $20-25 \%$ \\
\hline $\begin{array}{l}\text { Political youth organizations, young } \\
\text { environmentalists, etc. }\end{array}$ & $15-20 \%$ \\
\hline $\begin{array}{l}\text { Religious (Christian) } \\
\text { organizations }\end{array}$ & $\begin{array}{l}\text { CSOs that organize religious education and } \\
\text { activities based on religious affiliation }\end{array}$ & $10 \%$ \\
\hline
\end{tabular}

*This categorization follows the categories defined by Laitinen \& Taavetti (2016) and is based on the names and main purposes of the organizations. An exact categorization is not possible with the restricted data available, as many organizations serve several interrelated interests by, e.g., emphasizing educational aims in their free time activities.

The main methodological approach is based on frame analysis. Frames and frameworks, as originally introduced by Goffman (1974), refer to how individuals organize social experience in order to make sense of it and to guide future action. Goffman's grounding ideas have later been developed to facilitate frame analyses of other actors than the individual, including organizations (Cornelissen \& Werner, 2014) and social movements (Benford \& Snow, 2000; Johnston, 2002; Lindekilde, 2014). In the study of social movements, framing is seen as an active process in which frames are based on shared beliefs, shaped and shared by several individuals collectively and have a function in guiding their action. This emphasis on assuming strategic rationality in the framing process and paying attention to the active usage of frames in mobilizing adherents causes frame analysis to differ from the closely related discourse analysis, which often looks more closely at the composition, patterns and structures of texts, and aims to understand how they reflect the discursive context (Johnston, 2002; Lindekilde, 2014).

To understand how Finnish youth CSOs frame their approaches to youth participation, I used the analytical tool introduced by Benford \& Snow (2000). According to it, when social movements plan, decide and communicate what to do, they analyze the current situation (diagnostic framing), produce solutions for the future (prognostic framing), and create motives for action (motivational framing) for those involved. Additionally, I applied the idea of frame alignment processes. These help organizations create resonance between the participants' interests, values, and beliefs and the ideology, goals, and activities of the organization; by bridging, amplifying, extending, or transforming their framings, organizations can expand their scope and reach out to new potential participants and supporters (Snow et al., 1986). 
In this research, I gathered three sources of data: 82 websites, 65 annual reports and 17 interviews. These three data sets complement each other in terms of their selection method, content, and audience. The analysis took place in three phases.

First, I analyzed the contents of each of the 82 websites and collected information about the practical participation opportunities the organizations offer to young people. The results are presented in Table 2 .

Second, I carried out a qualitative frame analysis of the interview data. The semistructured interviews were conducted by myself during 2015-2016 with the employed leaders of 17 youth CSOs, intentionally selected to cover a variety of organizations, including big, small, old, and young CSOs with various main purposes. Using Atlas.ti, I looked for definitions and expressions of young people, youth participation, membership, volunteering, and relationships between youth and adults. I found more than 700 quotations that I organized into 31 relatively broad thematic codes. The coding served the purpose of organizing and condensing the data which I then classified according to the analytical questions of diagnostic, prognostic and motivational framing as shown in Table 3. The table also includes the five frames that I identified as a result of this phase.

Third, I proceeded to investigate how the various CSOs make use of the five frames and how this use is combined with practical participation opportunities. I collected annual reports from 65 of the 82 youth CSOs (mostly from 2014) and coded the data by member and volunteer roles, other participation opportunities, and definitions of young people as indications for the five frames. After that, I organized the data in order to analyze relationships between the frames and the participation opportunities and to find out how the various CSOs made use of them. Cross-checking the findings with those from the analysis of website data, I found that three frames of the five stood out: Almost all CSOs framed their main approach to youth participation according to one of the three whereas the remaining two frames were used in a complementary manner. Thus, this phase showed that the five frames were hierarchically organized (see Johnston, 2002) into three master and two subordinate frames and that their use was reflected in the practical participation opportunities available to young people (see Figure 1).

The triangulation of both data and analytical methods gives a firm basis to argue that the results give a reliable picture of the overall reality of Finnish nationwide youth CSOs that have at least one employee. What the results do not cover are opportunities for participation at local and regional levels, opportunities in CSOs that function on a voluntary basis, or the experiences of the young participants themselves.

\section{Results}

This study aimed to find out how Finnish youth CSOs frame their approaches to youth participation and what these framings mean in terms of practical participation opportunities for young people. This section presents the empirical results. It starts with a quantitative overview of participation opportunities in the CSOs and continues with the qualitative results of the frame analysis. 
Table 2. Participation opportunities for youth as described on the websites of Finnish nationwide youth CSOs

\begin{tabular}{|l|l|}
\hline Participation opportunity & $\begin{array}{l}\text { Number of youth CSOs } \\
\mathrm{n}=82\end{array}$ \\
\hline Membership & \\
- actively promoted on the front page & 27 \\
- mentioned on a subpage & 20 \\
- not mentioned & 11 \\
\hline Volunteering & 24 \\
- actively promoted on the front page & 17 \\
- mentioned on a subpage & 11 \\
\hline Leisure time activities & 54 \\
- actively promoted on the front page & 21 \\
- mentioned on a subpage & 5 \\
\hline None of the above & 56 \\
\hline
\end{tabular}

\section{Practical participation opportunities}

A quantitative look at the websites of 82 Finnish nationwide youth CSOs (Table 2) shows that membership is the most common way to invite young people to join youth CSOs in Finland. 27 organizations promote membership on the front page of their website; 20 of these CSOs present membership as the sole opportunity to participate. Another $20 \mathrm{CSOs}$ mention membership as an option. Volunteering opportunities are far less common: Eight CSOs, out of the 17 that actively promote volunteering, present volunteering as the only option for participation. Leisure time activities are usually presented along with opportunities to participate as a member or a volunteer; 21 organizations actively invite children and young people to join in these activities, but only four give it as the only option.

Given that all of the 82 organizations are primarily identified as youth CSOs, it is somewhat surprising to notice that nineteen organizations do not invite youth participation at all on their websites. Instead, they target youth indirectly through adult professionals, reach out to young people using other means than the internet, or focus on serving local associations or other organizations in their tasks as federations or umbrella associations.

The idea of membership as the foundation for associational life is thus still valid in most Finnish nationwide youth CSOs, despite the general belief that today's youth are not interested in memberships. It is noteworthy, however, that the number of members is one criterion for public funding for many youth CSOs in Finland. This increases the motivation of CSOs to have large numbers of registered members. The idea of inviting young people to join as checkbook members is very clearly phrased in the following extract from the website of a religious youth CSO: 
You do not need to be a member to join our activities, but we need members to get funding from the state. Membership is thus an effortless way of making our work possible also in the future! (P72, website)

\section{Three master frames based on the main orientation towards youth}

The frame analysis resulted in five frames that I named according to how they define young people. In Table 3, they are organized according to how much power and agency young people have in them. In the first frame, young people themselves are the main agents with power. The role of adults increases gradually going down Table 3, thus reflecting the idea of the ladder of participation (Hart, 1992).

Most of the studied CSOs were found to frame their approaches to youth participation according to one of three frames. In the first of these master frames, youth as agents, young people are seen as capable agents who have interests, opinions, and skills to promote their interests in organizations of their own without adult intermediaries. Youth interest organizations and activist youth CSOs whose members are young typically frame their approaches to youth participation along these lines.

Within this frame, large numbers of members increase the impact and credibility of the organization. Consequently, these organizations mainly invite young people to join as members on their websites. Even though the ideal is to have active members, participation opportunities allow checkbook members who give a mandate to the organization to promote their interests or support the cause of the organization. The main challenges include how to improve member recruitment, avoid oligarchy, and implement 'the principle that the whole membership is taken into account instead of arranging activities just on the activists' terms', as one of these CSOs wrote in its annual report.

The second master frame is called youth as learners and refers to children and youth that are seen as growing individuals with needs for personal development, not yet knowing what is best for them but capable of many things when instructed and supported by adults. The role of adult professionals and trained volunteers is to support young people to grow into balanced individuals, good adults, or active citizens by informal education. The power to decide what the CSO does is typically held by adults, but children and youth are encouraged to experience agency within specific activities or by the use of empowering educational methods. 
Table 3. Approaches to youth participation in Finnish nationwide youth CSOs (master frames in bold font)

\begin{tabular}{|c|c|c|c|c|}
\hline FRAME & $\begin{array}{l}\text { What is the current } \\
\text { state of youth } \\
\text { participation? } \\
\text { (diagnostic framing) }\end{array}$ & $\begin{array}{l}\text { What needs to be } \\
\text { done to improve the } \\
\text { situation? } \\
\text { (prognostic framing) }\end{array}$ & $\begin{array}{l}\text { Who needs to make } \\
\text { the change? }\end{array}$ & $\begin{array}{l}\text { Why do we need } \\
\text { youth participation? } \\
\text { (motivational } \\
\text { framing) }\end{array}$ \\
\hline $\begin{array}{l}\text { Youth as } \\
\text { agents }\end{array}$ & $\begin{array}{l}\text { The voice of the } \\
\text { young is not heard, } \\
\text { i.e., inefficient } \\
\text { democracy. }\end{array}$ & $\begin{array}{l}\text { Increase the number } \\
\text { of committed, active, } \\
\text { and skilled young } \\
\text { members. }\end{array}$ & $\begin{array}{l}\text { Young people } \\
\text { themselves }\end{array}$ & $\begin{array}{l}\text { To improve } \\
\text { democracy by } \\
\text { having active young } \\
\text { people make an } \\
\text { impact in the } \\
\text { society. }\end{array}$ \\
\hline $\begin{array}{l}\text { Youth in need } \\
\text { of facilitation }\end{array}$ & $\begin{array}{l}\text { Too few young } \\
\text { people take active } \\
\text { roles in CSOs. }\end{array}$ & $\begin{array}{l}\text { Create different } \\
\text { easy-to-access ways } \\
\text { for those young } \\
\text { people who do not } \\
\text { know how/have } \\
\text { courage/motivation } \\
\text { to be active. }\end{array}$ & $\begin{array}{l}\text { Adult professionals } \\
\text { and volunteers, more } \\
\text { experienced youth }\end{array}$ & $\begin{array}{l}\text { Active participation } \\
\text { is part of the main } \\
\text { idea of CSOs. }\end{array}$ \\
\hline $\begin{array}{l}\text { Youth as } \\
\text { learners }\end{array}$ & $\begin{array}{l}\text { All children and } \\
\text { young people do not } \\
\text { yet have the } \\
\text { opportunity to learn } \\
\text { in CSOs. }\end{array}$ & $\begin{array}{l}\text { Reach out to more } \\
\text { children and young } \\
\text { people in different } \\
\text { social groups and } \\
\text { life situations. } \\
\text { Improve the quality } \\
\text { of activities to allow } \\
\text { more learning. }\end{array}$ & $\begin{array}{l}\text { Adult professionals } \\
\text { and trained } \\
\text { volunteers }\end{array}$ & $\begin{array}{l}\text { Participation } \\
\text { opportunities are } \\
\text { good for personal } \\
\text { development and for } \\
\text { learning active } \\
\text { citizenship skills. }\end{array}$ \\
\hline $\begin{array}{l}\text { Youth as } \\
\text { targets of } \\
\text { support }\end{array}$ & $\begin{array}{l}\text { Young people have } \\
\text { problems that can be } \\
\text { tackled by reaching } \\
\text { out to them with } \\
\text { participatory } \\
\text { activities. }\end{array}$ & $\begin{array}{l}\text { Reach out better to } \\
\text { those in need, show } \\
\text { results, create } \\
\text { partnerships with } \\
\text { other actors }\end{array}$ & $\begin{array}{l}\text { Adult professionals, } \\
\text { sometimes peer } \\
\text { volunteers }\end{array}$ & $\begin{array}{l}\text { Participation is a } \\
\text { means to prevent } \\
\text { exclusion and to } \\
\text { enhance } \\
\text { individual } \\
\text { empowerment. }\end{array}$ \\
\hline $\begin{array}{l}\text { Youth, adults } \\
\text { or other } \\
\text { organizations } \\
\text { in need of } \\
\text { services }\end{array}$ & $\begin{array}{l}\text { There is a demand } \\
\text { for services within } \\
\text { the field of } \\
\text { participation. }\end{array}$ & $\begin{array}{l}\text { Improve the quality } \\
\text { and increase the } \\
\text { quantity of services, } \\
\text { find more customers. }\end{array}$ & $\begin{array}{l}\text { Adult professionals, } \\
\text { sometimes trained } \\
\text { volunteers }\end{array}$ & $\begin{array}{l}\text { Organizing } \\
\text { opportunities for } \\
\text { participation or } \\
\text { building capacity to } \\
\text { do so is a needed } \\
\text { service. }\end{array}$ \\
\hline
\end{tabular}

This frame is primarily used by CSOs with the main purpose of leisure time activities and youth education; religious organizations often apply this frame as well. Informal education is typically seen as a task accomplished by reaching out to all young people. Consequently, these CSOs often cooperate with schools, municipal youth clubs, or other actors that help them to reach out to broad audiences. It is interesting to note that the goal of educating active citizens often aims to serve the society as a whole: Young people are educated to understand the idea of democracy and vote, become critical media 
users and consumers, learn entrepreneurial skills, etc., as is characterized in the following extract from the website of one of these CSOs:

The [...] Club instils practical skills and knowledge with the help of professional instructors. Training and courses further build on these competencies. The activities help children become active citizens, entrepreneurs and employees. (P1, website)

This second frame is often combined with providing opportunities for volunteering in club tutoring and camp leading tasks as serious leisure that is seen as a means for learning as well. The relationship to membership is more complex. Some organizations assume membership as the natural way to join their activities, including the idea of gradually starting to take responsibility for arranging activities for others as active members. However, it is more common that children and young people are encouraged to join activities without emphasizing the idea of membership or becoming committed to the CSOs as such. Instead, a membership fee may be included in the registration fee for activities, or participants may be encouraged to sign up as members in order to get reductions in activity fees. These result in pay and play or consumer-memberships.

The third master frame, youth as targets of support, refers to the observed needs of specific groups of young people at risk of marginalization. Adults have a role in reaching out to these youth and providing support, and the purpose of participation is social inclusion in terms of care and belonging. The adults support the youth in developing motivation and skills needed to make use of opportunities provided by the overall society (education, apprenticeships, etc.) and feelings of belonging to a group, which can gradually lead to personal empowerment, improved behavioural patterns and finding a decent place in the society. Participation thus means building ground for starting to 'participate in their own life, take the evening bath and the medication, plan to go to school etc.' as one interviewee expressed it.

This frame is most often used by youth CSOs that specialize in social reinforcement, including more specific issues such as prevention of substance abuse or patterns of undesirable behaviour. The targeted youth are normally not expected to become members or volunteers. In fact, most organizations using this frame seem to find the overall meaning of membership less relevant. Some of them are registered as foundations, and even the registered associations in this group have very small memberships, mainly consisting of the few people who initially founded the organization. The power is in the hands of experts and the work is carried out by adult professionals or benevolent volunteers. At the same time, the working methods in projects or activities that focus on vulnerable youth often use participatory methods or allow creative spaces (Tsekoura, 2016) where the participants are empowered to start taking responsibility for their own behaviour and influencing the group-level activities.

Most Finnish nationwide youth CSOs frame their approaches to youth participation along the lines of one master frame that reflects the main purpose of the organization. Some of the biggest CSOs may employ several framings by focusing on different types of young people in the different departments of the organization or by allocating specialized employees for the specific approaches. In addition, there are a 
couple of interesting newer CSOs that combine elements of two frames. They are established and run by young people themselves (youth as agents) with the aim of supporting youth at risk (youth as targets of support). They see it as the right and responsibility of young people themselves to create solutions for their peers in need of support and believe that even vulnerable youth can potentially become active volunteers. Differently from other CSOs using the youth as agents frame, however, the role of membership is not very central, if used at all.

Another irregular case can be found in older activist organizations. On the one hand, they are based on the idea of youth as agents promoting peace, environmental issues or other things that require changes in the society. On the other hand, because of the age of the CSOs, many of their originally young members have grown older and see that today's youth are ignorant about the big issues that the CSO aims to tackle, which results in framing youth participation along the lines of youth as learners.

\section{Subordinate frames help to expand the scope of the CSO}

The remaining two frames, youth in need of facilitation (later facilitation) and youth, adults or organizations in need of services (later service provision), do not directly reflect the main purpose of the organizations. They are thus used mostly as complementary subordinate frames (see Figure 1) and reflect the idea of frame alignment processes which help CSOs to expand their scope and seek resonance among broader audiences (see Snow et al., 1986) such as new focus groups, potential sponsors and other actors in the society.

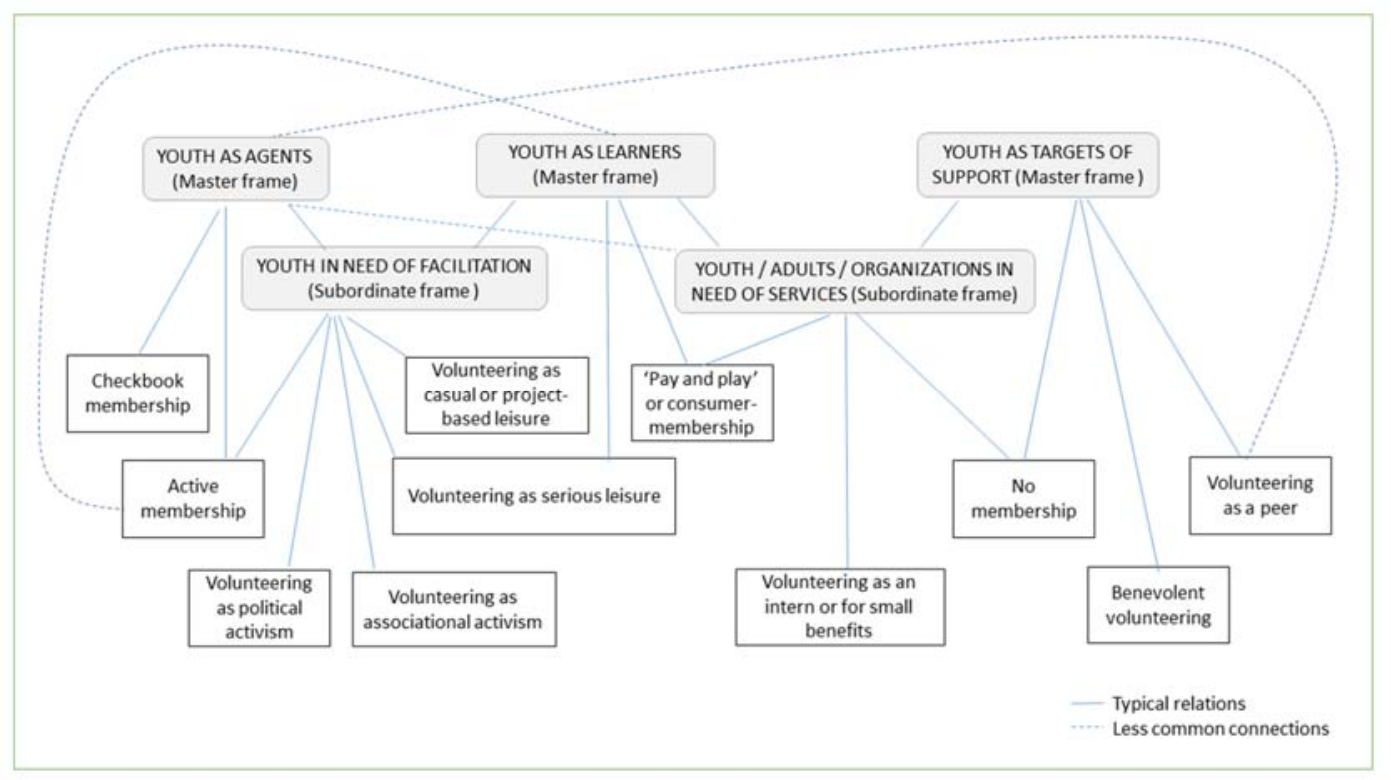

Figure 1. Youth participation frames and their relationships to participation opportunities

The first subordinate frame, facilitation, responds directly to the main concern of this article and refers to the need to encourage young people to take active roles in CSOs. This results from the observation that not all young people are willing, capable, or 
courageous enough to take responsibility for the various tasks within a $\mathrm{CSO}$, or do not want to make long term commitments. Thus, CSOs need to facilitate the participation of new potential actors by arranging easy-to-access ways to become active. In practice, this means that the organizations open up opportunities to join the CSO in varying member and volunteering roles including short-term options like volunteering as casual or projectbased leisure, often facilitated by adult professionals or volunteers, and sometimes also by more experienced youth.

This subordinate frame is typically used by organizations with the primary frames of youth as agents and youth as learners. For the youth as agents organizations, it opens an opportunity to encourage participation by young people who are not interested in joining the organization in traditional member roles but may take on a short term volunteering task. The facilitation frame is a way to expand the scope from politics and advocacy into the field of youth work in terms of encouraging new young people to join in open events or training functions, taking care of smaller practical tasks, or on a project basis in specific campaigns, etc. It is thus one way for these youth CSOs to respond to the criticism that they only reach out to already active and better-off young people and to create wider resonance with the purposes of the Youth Act.

For organizations mainly using the youth as learners frame, the facilitation frame opens up the opportunity to encourage young people to also become active within the CSO rather than only taking part in activities arranged by others. This means that the organizations encourage young people to participate in the arrangement of activities and in the decision-making structures of the organization. These facilitation components can be seen as an effort these CSOs take to preserve elements of the traditional ideals of CSOs where members essentially own, govern, carry out and benefit from the organization, and avoid becoming just service providers to youth. A newer, related phenomenon is the rise of voluntary youth teams, youth parliaments or youth advisory groups that are also found in some umbrella organizations that do not otherwise deal directly with young people. These new bodies are not part of the democratic structure of the CSO but act as channels for youth ideas, help renew the organization, and let the organization, mainly run by adults, reflect on some issues from the youth's point of view. They are partly motivated by the goal of enabling young people to have an influence in the organization or to learn about associational activity, partly by referring to elements of client participation, which is related to the second subordinate frame.

In the second subordinate frame, service provision, children and youth or adults and organizations trying to reach out to them are seen as needing services produced by skilled experts. These services can take different forms such as daycare services, clubs, hobbies, courses, exchange programs or other activities that children and young people can participate in without the need to be involved in arranging them. The idea of a service is also used when youth participation is defined as an expert product that can be sold as facilitation or training services to clients.

This frame thus extends youth participation into the area of service production, looking for participation needs that someone is willing to pay for or fund. Even children and youth are seen as customers who (or whose parents) buy the service if they consider it worth the cost. Hearing the voices of children and young people takes place under the 
realm of client democracy, i.e., aiming at receiving feedback from customers to improve the quality of services. The requirements for good quality mean that most services are produced on a professional basis. Those that use volunteers mainly do so to cut the costs of arranging the activities. In these cases, the volunteers are motivated by small benefits or the possibility to improve their resume.

This subordinate frame is used by some of the youth as learners and youth as targets of support organizations, in rare cases also by some youth as agents organizations that use it to attract checkbook members by emphasizing membership benefits in their marketing efforts. The frame enables expansion of the scope of these organizations into a more business-like world, which supports the fundraising efforts of these CSOs and resonates with the requirements of professionalism in the overall society today. It makes use of commercial language: The organizations provide hobbies, sell expert services or initiate projects on a market where participation is based on the principles of demand and supply. It is also helpful in motivating sponsors to fund projects that require professional approaches, as is often the case in outreach projects to youth at risk or in marginal positions. Using this frame, also youth as learners organizations can expand their activities into that field.

\section{Conclusion and Discussion}

This article set out to explore how Finnish nationwide youth CSOs define and implement youth participation. It also sought to understand how these CSOs contribute to young people's attachment to and integration into CSOs. The investigated CSOs frame their approaches to youth participation in five main ways and complement each other by focusing on various types of young people and giving them opportunities to participate in a great variety of roles. In fact, all member and volunteer roles identified in earlier international research can be found among the Finnish youth CSOs. In addition to those key roles, young people are approached as participants in leisure time activities, targets of support and clients.

Moreover, all but one of the main approaches to youth participation identified by earlier researchers were found among the investigated CSOs; only the idea of participation as social justice (see Shaw et al., 2014) was not found in the data. This raises the question of why the social justice approach is missing. Do Finnish CSOs trust the justice and efficacy of the welfare society so much that they do not perceive a need to fight for social justice, or do they just follow government policies that lack encouragement for CSOs to include social justice in their agendas? Another line of explanation is that youth participation as social justice takes place in smaller, local, or less established identity or minority groups that are not limited to youth or do not reach up to the national level. Further research is needed to understand this better.

Membership is still the most common way for nationwide Finnish youth CSOs to approach young people. However, it is the only or dominant way almost exclusively in activist and interest types of CSOs. The results also suggest that member roles are also changing in a context where both CSO culture and public funding criteria support membership. Moreover, the findings support the idea that the primary aim of the 
organization makes a difference when deciding on the repertoires of participation (see van der Meer et al., 2009).

This research builds on earlier research on membership and volunteering and deepens it by adding the perspective of youth participation. The results show that the only role directly linked with integration and agency in Finnish youth CSOs is active membership. Somewhat surprisingly, checkbook membership, despite its image as a passive role, is also presented here as an active and conscious role that integrates the member into the CSO. Roles that are framed as including little or no attachment to or integration into the CSO itself include participants without membership, clients, pay-andplay or consumer members, and often also, surprisingly, both benevolent volunteers and volunteers as interns or for small benefits. Other volunteering roles can be framed either as individual learning opportunities or as roles including or leading to agency in the CSO. These observations show the relevance of investigating not only how the roles are named but also how they are framed. They also show that as much as 'menus of volunteering' can cause individualized volunteering (Hustinx, 2010; Read, 2010), 'menus of participation' can be framed to enable integration in the CSO or create loose or no connections to the organization behind the activities.

At the same time, the findings do not appear to support the assumption that big CSOs become oligarchic and give less space to members (Michels, [1911], 1962; Skocpol, 2013). On the contrary, there are some smaller CSOs with strong hybrid characters (Billis, 2010) that seem to have far less or no space at all for young people to influence decision-making.

The results make an important contribution to the discussion of young people's integration into CSOs by showing the differences between approaches to youth participation. At one extreme, some CSOs base their whole future existence on young people's participation and depend on finding new young people to take over when the previous ones become too old. At the same time, however, they run the risk of focusing only on the small number of already active and well-off young people who are interested in taking part in traditional member roles as 'young adults' (Thomas, 2007). At the other extreme, some CSOs reach out to less privileged young people, support them in personal youth development (Lerner et al., 2005), or provide services that help young people to fill their basic needs and gradually become balanced adults, future employees, and active citizens. By doing this they contribute to the future of general social participation (van Ingen, 2009) and serve the needs of the overall society, but do not necessarily pay any attention to integrating young participants into CSOs.

The results also show that many Finnish youth CSOs have started to respond to the challenge of integrating young people into them, notably by paying specific attention to potentially interested young people who need facilitation. However, facilitation is not only a question of will; it also needs people, in most cases employed professionals. The question is how CSOs with few employees can handle the situation: Do they primarily fulfill the expectations of the current members, implement projects with separate funding, write applications and reports to sponsors, etc., or do they organize and facilitate the participation of new potential young people? Do they even have the capacity to do all of 
this? These are questions of policy for both CSOs and sponsors, who set the criteria for how their grants are used.

The issue of resources is linked to the observation that several of the investigated CSOs approach youth participation as a service, thus bringing the questions of youth participation into the sphere of business. Given the prospect of declining member fees among young people who are not willing to commit themselves as members (Lochocki, 2010; Merikivi et al., 2016) it is understandable when youth CSOs start to look for resources by other means, for example by selling services. At the same time, this development can be seen as part of the discussion of hybrid organizations that emphasize the role of employed professionals and see voluntary actors mostly as customers or as one type of resource (Billis, 2010; Ellis Paine et al., 2010). A key question for the decision makers of the CSOs, funding agencies with their policies, and future research is whether the logic of business can be combined with the idea of enabling young people to take active roles in building the future of CSOs. The results of this study raise doubts about whether combining these approaches is possible in contexts other than big CSOs with several departments, but more detailed investigation of the internal processes of the organizations is needed to understand this better.

In sum, this article has brought together key elements and concepts from previous research on membership, volunteering, and associational involvement and looked at them in the framework of youth participation. By doing this, it has integrated discussions that, up till now, have taken place separately, and shown how they are linked in the context of nationwide Finnish youth CSOs. The identified frames will be useful for future research on associational activism and social participation from a youth perspective in other countries and other contexts, for example in CSOs that do not specifically focus on youth but where they are one of the possible participant groups. 


\section{References}

Associations Act (1989) (Yhdistyslaki 503/1989) Available at www.finlex.fi_(accessed 16 April 2017).

Barrett, M. \& Brunton-Smith, I. (2014) Political and Civic Engagement and Participation: Towards an Integrative Perspective, Journal of Civil Society, 10(1), pp. 5-28.

Benford, R.D. \& Snow, D.A. (2000) Framing processes and Social Movements: An overview and Assessment. Annual Review of Sociology, 26, pp. 611-639.

Billis, D. (2010) Towards a theory of hybrid organizations, in: D. Billis (Ed) Hybrid Organizations and the Third Sector. Challenges for Practice, Theory and Policy, pp. 46-69 (Basingstoke and New York: Palgrave Macmillan).

Cornelissen, J.P. \& Werner, M.D. (2014) Putting Framing in Perspective: A Review of Framing and Frame Analysis across the Management and Organizational Literature, The Academy of Management Annals, 8(1), pp. 181-235.

Eliasoph, N. (2011) Making volunteers. Civic life after welfare's end (Princeton and Oxford: Princeton University Press).

Ellis Paine, A, Ockenden, N. \& Stuart, J. (2010) Volunteers in hybrid organizations: A marginalised majority? In: D. Billis (Ed): Hybrid Organizations and the Third Sector. Challenges for Practice, Theory and Policy, pp. 93-113 (Basingstoke and New York: Palgrave Macmillan).

Feldmann-Wojtachnia E., Gretschel A., Helmisaari, V. Kiilakoski, T., Matthies,A-L., Meinhold-Henschel, S. Roth,R. \& Tasanko, P. (2010) Youth participation in Finland and in Germany. Status analysis and data based recommendations (The Finnish Youth Research Network \& Forschungsgruppe Jugend \& Europa am CAP). Available at http://www.nuorisotutkimusseura.fi/images/julkaisuja/youth_participation_in_fi nland_and_in_germany.pdf (accessed 16 June 2017).

Flash Eurobarometer 375 (2013) European youth: Participation in democratic life. Available at http://ec.europa.eu/public_opinion/flash/fl_375_en.pdf (accessed 15 March 2017).

Goffman, E. (1974) Frame Analysis. An Essay on the Organization of Experience (Cambridge, Massachusetts: Harvard University Press).

Gretschel, A., Levamo, T-M., Kiilakoski, T., Laine, S., Mäntylä, N., Pleyers G., \& Raisio, H. (2014) Youth Participation. Good Practices in Different Forms of Regional and Local Democracy (Finnish Youth Research Network and Finnish Youth Research Society). Available at http://www.nuorisotutkimusseura.fi/images/julkaisuja/youthparticipation_goodp ractices.pdf (accessed 25 April 2017).

Harris, A., Wyn, J. \& Younes, S. (2010) Beyond apathetic or activist youth. 'Ordinary' young people and contemporary forms of participation, Young 18(9), pp. 9-32.

Hart, R.A. (1992) Children's participation: From tokenism to citizenship Innocenti Essays No. 4. UNICEF International Child Development Centre. Florence, Italy. 
Henriksen, L.S. \& Svedberg, L. (2010) Volunteering and Social Activism: Moving beyond the Traditional Divine, Journal of Civil Society, 6(2), pp. 95-98.

Holmes, K. \& Slater, A. (2012) Patterns of Voluntary Participation in Membership Associations: A Study of UK Heritage Supporter Groups, Nonprofit and Voluntary Sector Quarterly, 41(5), pp. 850-869.

Hustinx, L. (2010) Institutionally Individualized Volunteering: Towards a Late Modern Re-Construction, Journal of Civil Society, 6(2), pp. 165-179.

Hustinx, L. \& Denk, T. (2009) The 'Black Box' Problem in the Study of Participation, Journal of Civil Society, 5(3), pp. 209-226.

Hustinx, L. \& Lammertyn, F. (2003) Collective and Reflexive Styles of Volunteering: A Sociological Modernization Perspective, Voluntas, 14(2), pp. 167-187.

Johnston, H. (2002) Verification and Proof in Frame and Discourse Analysis, in: B. Klandermans \& S. Staggenborg (Eds.) Methods of Social Movement Research, pp. 62-91 (Minneapolis, London: University of Minnesota Press).

Laitinen, H. \& Taavetti, R. (2016) Valtakunnalliset nuorisojärjestöt ja nuorten osallistumismahdollisuudet, Yhteiskuntapolitikka, 81(1), pp. 55-68.

Lerner, R.M., Almerigi, J.B., Theokas, C., Lerner, J.V. (2005) Positive Youth Development. A View of the Issues, Journal of Early Adolescence, 25(1), pp. $10-16$.

Lindekilde, L. (2014) Discourse and Frame Analysis. In: D. della Porta (Ed) Methodological Practices in Social Movement Research, pp. 195-227 (Oxford: Oxford University Press).

Lochocki, T. (2010) Trends, Causes and Patterns of Young People's Civic Engagement in Western Democracies. A review of literature (Oslo/Bergen: Centre for Research on Civil Society and Voluntary Sector).

Lorentzen, H. \& Hustinx, L. (2007) Civic Involvement and Modernization, Journal of Civil Society, 3(2), pp. 101-118.

Merikivi, J., Myllyniemi, S. \& Salasvuo, M. (Eds) (2016) Media hanskassa. Lasten ja nuorten vapaa-aikatutkimus 2016 mediasta ja liikunnasta (Opetus- ja kulttuuriministeriö, Nuorisotutkimusverkosto, Nuorisoasiain neuvottelukunta, Valtion liikuntaneuvosto). Available at http://www.nuorisotutkimusseura.fi/images/julkaisuja/media_hanskassa.pdf (accessed 16 June 2017).

Michels, R. ([1911] 1962) Political Parties. A sociological Study of the Oligarchical Tendencies of Modern Democracy (New York: The Free Press. A Division of Macmillan Publishing Co. Inc., Collier Macmillan Canada, Ltd). First published in German 1911.

Peltosalmi, J., Eronen, A., Litmanen, T. \& Ruuskanen, P. (2016) Järjestöbarometri. (Helsinki: SOSTE Suomen sosiaali ja terveys ry).

Putnam, R.D. (2000) Bowling alone. The Collapse and Revival of American Community (New York: Simon \& Schuster).

Rochester, C., Paine, A.E., Howlett, S. \& Zimmeck, M. (2010) Volunteering and Society in the $21^{\text {st }}$ Century (Hampshire: Palgrave Macmillan). 
Read, R. (2010) Creating reflexive volunteers? Young people's participation in Czech hospital volunteer programmes, Journal of Youth Studies, 13(5), pp. 549-563.

Salamon, L.M., Sokolowski, S.W. \& List, R. (2003) Global Civil Society. An Overview. (Baltimore: The Johns Hopkins University. Institute for Policy Studies. Center for Civil Society Studies).

Shaw, A., Brady, B., McGrath, B., Brennan, M.A. \& Dolan, P. (2014) Understanding youth civic engagement: debates, discourses, and lessons from practice, Community Development 45(4), pp. 300-316.

Siisiäinen, M. (1988) Nuorisojärjestöt itsenäisessä Suomessa. (Jyväskylä: Jyväskylän yliopiston sosiologian laitoksen julkaisuja 43).

Siisiäinen, M. \& Blom, R. (2009) Associational Activeness and Attitudes towards Political Citizenship in Finland from a Comparative Perspective, Journal of Civil Society, 5(3), pp. 265-281.

Schofer, E. \& Fourcade-Gourinchas, M. (2001) The structural context of civic engagement: Voluntary association membership in comparative perspective, American Sociological Review 66(6), pp. 806-828.

Skocpol, T. (2003) Diminished Democracy: From Membership to Management in American Civic Life (Norman, OK: University of Oklahoma Press).

Snow, D.A., Burke Rochford, E. Jr., Worden, S.K., \& Benford, R.D. (1986) Frame Alignment Processes, Micromobilization and Movement Participation, American Sociological Review 51(4), pp. 464-481.

Stebbins, R.A. (2004) Introduction, in: R. A. Stebbins \& M. Graham (Eds) Volunteering as Leisure / Leisure as Volunteering: An International Assessment, pp. 1-12 (Wallingford, UK; Cambridge, MA: CABI Publishing).

Stebbins R. A. \& Graham M. (Eds) Volunteering as Leisure / Leisure as Volunteering: An International Assessment (Wallingford, UK; Cambridge, MA: CABI Publishing).

Thomas, N. (2007) Towards a Theory of Children's Participation, International Journal of Children's Rights 15, pp. 199-218.

Tsekoura, M. (2016) Spaces for Youth Participation and Youth Empowerment: Case Studies from the UK and Greece, Young 24(4), pp. 1-16.

van der Meer, T.W.G., te Grotenhuis, M. \& Scheepers, P.L.H. (2009) Three Types of Voluntary Associations in Comparative Perspective: The Importance of Studying Associational Involvement through a Typology of Associations in 21 European Countries, Journal of Civil Society, 5(3), pp. 227-241.

van der Roest, J-W., van Kalmthout, J. \& Meisj, L. (2016) A consumerist turn in Dutch voluntary sport associations? European Journal for Sport and Society, 13(1). pp. $1-18$.

van Ingen, E.J. (2009) Let's come together and unite: Studies of the changing character of voluntary association participation (Ridderkerk: Ridderprint).

Walker, E.T., McCarthy, J.D. \& Baumgartner, F. (2011) Replacing Members with Managers? Mutualism among Membership and Nonmembership Advocacy Organizations in the United States, American Journal of Sociology. 116(4), pp. 1284-1337. 
Youth Act 2016 (Nuorisolaki 1285/2016). Available at www.finlex.fi_(accessed 16 April 2017).

i Researchers differ in which of the two concepts ('youth participation' or 'youth civic engagement') they use even though the phenomena they pay attention to are closely related, strongly overlapping or in some cases the same. In the interest of consistency with the topic of this article, the concept 'youth participation' is primarily used here.

${ }^{\text {ii }}$ In practice, this includes member organizations of the national network Finnish Youth Cooperation - Allianssi and CSOs that have applied for governmental funding (2013-2014) as nationwide youth/youth work organizations, counting those where $2 / 3$ or more of the members are young or that have youth as the main focus or youth work as the main purpose (see also Laitinen \& Taavetti, 2016). 